\title{
Conservation units, ecological attributes and their implications: The case of the Park and EPA of the Pireneus/GO
}

\author{
Unidades de Conservação, atributos ecológicos e suas implicações: \\ o caso do Parque Estadual dos Pireneus e da APA dos \\ Pireneus - GO \\ Joana D’Arc Bardella Castro ${ }^{a}$ \\ Talita Freitas Souza Barros ${ }^{b}$ \\ Murilo Rodrigues da Silva ${ }^{c}$ \\ Maurício Gabriel Santos ${ }^{\mathrm{d}}$
}

${ }^{a}$ Doutora em Economia, Professora Titular da Universidade Estadual de Goiás, Anápolis, GO, Brasil E-mail: joanabardella@brturbo.com.br

${ }^{b}$ Mestranda em Recursos Naturais do Cerrado, Universidade Estadual de Goiás, Anápolis, GO, Brasil E-mail: economia.talita@gmail.com

'Mestrando em Recursos Naturais do Cerrado, Universidade Estadual de Goiás, Anápolis, GO, Brasil E-mail: murilorodrigues.ea@gmail.com

${ }^{d}$ Mestre em Educação, Linguagem e Tecnologia, Universidade Estadual de Goiás, Anápolis, GO, Brasil.

E-mail: mauricioipub@hotmail.com

doi:10.18472/SustDeb.v10n3.2019.24330

Received: 27/04/2019

Accepted: 21/10/2019

ARTICLE- DOSSIER

\begin{abstract}
The Environmental Protection Area of Pirineus (EPA) extends over 22,800 hectares around Pireneus Park - GO Park, bordering the cities of Pirenópolis, Cocalzinho de Goiás and mountainous areas of Corumbá de Goiás. The aim of the study was to verify if the municipalities bordering the EPA of Pirineus have benefited from these protected areas, providing local growth and development. This is a bibliographical, qualitative and documentary research. The satellite images Landsat- 5 e Landsat- 8 extracted from the catalog at Inpe's General Imaging Division, were used to the classification of land use and occupation in EPA, and to characterize the impact of the area were used the method of Oldekop et al. The results are presented descriptively and analytically. The creation of the Conservation Units of Pirineus, in addition to changing the socio-cultural context of the region, contributed to the population growth on average $11,46 \%$, the displacement of this to rural area in $27 \%$ in Cocalzinho, a $51 \%$ average increase in per capita income and an increase in development rates, such as a $30 \%$ increase in the HDI.
\end{abstract}


Keywords: Environment. Parks. Pirineus. Environmental Protection Area.

\section{RESUMO}

A Área de Proteção Ambiental (APA) dos Pireneus se estende por 22.800 hectares ao redor do Parque dos Pireneus - GO, margeando as cidades de Pirenópolis, Cocalzinho de Goiás e áreas serranas de Corumbá de Goiás. O objetivo do estudo foi verificar se os municípios limítrofes à APA dos Pireneus têm se beneficiado dessas unidades de conservação proporcionando crescimento e desenvolvimento local. Esta é uma pesquisa bibliográfica, qualitativa e documental. Fez uso das imagens de satélite Landsat-5 e Landsat-8 extraídas do catálogo na Divisão Geral de Imagens do Inpe para a classificação do uso e ocupação do solo na APA, e para caracterização do impacto da área usou-se o método de Oldekop e colaboradores. Os resultados são apresentados de maneira descritiva e analítica. A criação das Unidades de Conservação dos Pireneus, além de mudar o contexto sociocultural da região, contribuiu para o crescimento da população em média de $11,46 \%$, o deslocamento desta para área rural em $27 \%$ em Cocalzinho, aumento médio de 51\% da renda per capita e elevação de índices de desenvolvimento, como aumento do IDH em $30 \%$.

Palavras-Chave: Meio ambiente. Parques. Pireneus. Área de Proteção Ambiental.

\section{INTRODUCTION}

Conservation Units - UC are the safeguard for the maintenance and conservation of biodiversity and natural heritage. They also provide protection against climate change and natural disasters, ensuring ecological balance (UNEP, 2016). Protected areas emerge as a solution to local threats to biodiversity (SALGADO, 2000).

Parks and Areas of Environmental Protection are created to preserve the environmental asset and make the relationship between humans and nature more harmonious. But the creation of these preservation areas also means increased difficulties in managing financial resources, preserving space and creating a link between residents of neighboring municipalities

For this analysis was used the documentary literature search as well as satellite images Landsat- 5 and Landsat-8 extracted from the catalog at Inpe's General Imaging Division for the classification of land use and occupation in the EPA of Pirineus.

This study aims to verify if the municipalities bordering the State Park of Pirineus and the EPA of Pirineus have benefited from these protected areas. Therefore, it was necessary the socioeconomic and environmental description of the municipalities, to know their indicators of growth and development, and to verify the current situation of both the State Park of Pirineus and the EPA of Pirineus.

\section{LEGAL ASPECTS FOR THE APPEARENCE OF PARKS AND EPAS}

\subsection{THE NATIONAL SYSTEM OF CONSERVATION UNITS AND CATEGORIES: ENVIRONMENTAL PRESERVATION AREA}

The Environmental Protection Area - EPAs were created by the Law No 6.902/81, regulated by Decree No 99.274/90, and CONAMA Resolution No 10/1988. Referenced in Law No 9.985/2000 as "large areas, with a certain degree of human occupation, endowed with abiotic, biotic, aesthetic or cultural resources important for the life and well-being of the populations", their main objective is to protect the biological and disciplinary diversity or the process of occupation, thus ensuring a sustainable use of natural resources. 
EPAs are supervised by the competent bodies in accordance with the political sphere responsible for their management. If the administration is federal, the inspection is carried out by the Chico Mendes Institute for Biodiversity Conservation (ICMBio), state and municipal APAs are supervised by the equivalent body instituted by the state or municipality.

The Environmental Protection Area has the purpose of ensuring the fulfillment of the property's socioenvironmental function. The owner retains all powers inherent in the domain, but limited by the content of the Law, that is, does not annihilate the economic content of the property nor the exclusivity.

According to Leuzinger (2010), as a conservation unit, as EPAs must have an ecological-economic zoning, mainly because they are usually caused in already anthropized places, consequently degraded.

The zoning should allow the protection of the portion of its ecosystem, setting the norms of use, considering its biotic, abiotic, urbanistic characteristics, agricultural uses, extractive potential and cultural values (SANTOS, 2018). In EPAs, visits are allowed, provided that the recommendations of the management plan are observed. If it is a private property, it will depend on the owner's initiative.

The author also claims that to ensure sustainable management of conservation areas would require a Public Use Plan - PUP of the visitation site to minimize possible damage to property. Thus, the PUP defines sustainable ways of using UCs "to conserve their natural and historical attributes, through infrastructure analysis, demand study and optimization of activities, providing the user with the opportunity to interact in the best possible way with nature "(PENA; SANTOS; SINAY, 2013, p. 61)

Table 1 shows the distribution of PAs (Protected Areas) by Brazilian biome. It is noted that there is a higher concentration in the Atlantic Forest (198) with $83,745 \mathrm{~km}^{2}$, representing $7.5 \%$ of the biome, and in the Cerrado (73) occupying a total area of $109,176 \mathrm{~km}^{2}$, which represents $5.4 \%$ of the Cerrado.

Table 1 | Number of PAs per biome and its meaning of occupation in \% - 2018.

\begin{tabular}{|c|c|c|c|}
\hline Biome & Quantity & \% of Biome & Total Area of the Biome $\left(\mathrm{km}^{2}\right)$ \\
\hline AMAZON & 38 & 4,9 & 4.198 .551 \\
\hline CAATINGA & 35 & 6,3 & 827.934 \\
\hline CERRADO & 73 & 5,4 & 2.040 .167 \\
\hline ATLANTIC FOREST & 198 & 7,5 & 1.117 .571 \\
\hline PAMPA & 3 & 2,4 & 178.704 \\
\hline PANTANAL & 0 & 0 & 151.159 \\
\hline MARINE AREA & 67 & 1,3 & 3.555 .796 \\
\hline
\end{tabular}

Source: MMA/Cnuc, 2018.

There are 319 PAs throughout the territory with a coverage area of $499.631 \mathrm{~km}^{2}$ being that the largest amount is in the state sphere $(59.56 \%)$, followed by the municipal $(30.09 \%)$, and the rest is in the federal sphere (10.35\%) (MMA-CNUC, 2018). 


\subsection{FEDERAL, STATE AND MUNICIPAL PARKS}

The parks were originally governed by the Forest Code, regulated by Decree No. 84.017 / 1979. Currently, are regulated by Law No. 9,985 / 2000 which in its article 11 says that the main purpose of parks is:

the preservation of natural ecosystems of great ecological relevance and scenic beauty, enabling scientific research and the development of environmental education and interpretation activities, recreation in contact with nature and eco tourism.

Parks can be terrestrial and / or aquatic, usually extensive (over $10 \mathrm{~km}^{2}$ ), conciliating the protection of flora, fauna and natural beauty on lands within their domain. The possibility of visitation is mandatory (LEUZINGER, 2009).

Regarding expropriation of areas, Rocha, Drummond and Ganem (2010) believe that there is a low degree of public sector priority in solving land problems. Human presence in parks is directly related to building improvements that interfere with the ecosystem and incorporate value to the land. These contribute to the dismemberment and sale of land to people coming from outside the region who are interested in building a second residence, which in turn promotes the appearance of new actors, with new interests complicating the regularization of parks. Until 2012, only one federal park in Brazil had its situation regulated. In this regard, two well-defined currents debate the issue. The Chart 1 reports on the intrinsic aspects of the issue.

Chart 1 | Currents of thought about the presence or absence of humans residing in the Parks.

\begin{tabular}{|c|c|}
\hline Preservationists & Socioenvironmentalists \\
\hline Traditional Parks concept - no humans presence & $\begin{array}{l}\text { With presence of human activities such as primitive or } \\
\text { traditional threats }\end{array}$ \\
\hline Belief $1-$ The man is nature destroyer & $\begin{array}{l}\text { There are cultures that have developed a more } \\
\text { harmonious relationship with nature. }\end{array}$ \\
\hline $\begin{array}{l}\text { Belief } 2-\text { Untouched nature is that derived from natural } \\
\text { evolution }\end{array}$ & $\begin{array}{l}\text { Cultural diversity also needs to be conserved, both for } \\
\text { ethical reasons and as a tool for protecting traditional } \\
\text { knowledge, so it is part of nature. }\end{array}$ \\
\hline
\end{tabular}

Source: Composite chart based on text from Rocha, Drummond and Ganem (2010).

The creation of the parks did not occur on a regular way. Between 1937 and 1939 three parks were created in the South and Southeast; from 1959 to 1961 eleven parks in the South, Southeast, Northeast, and Midwest; ten years later three more parks were created in the Southeast and North; and from 1979 to 1986 plus eleven parks in the South, Southeast, Northeast, Midwest and North. Rocha, Drummond and Ganem (2010) emphasize that there was no balanced regional or ecosystem distribution. For a long time, the choice of parkland was the privilege of scenic beauty and ease of access for visitors. Around the 1960s, the rationale focused on leisure and tourism areas, especially the Cerrado biome.

In the 1980s, a visionary attitude prevailed: anticipate the process of occupation of more remote areas and include as UCs, provided the areas are in good ecosystem state and covering various biomes in the country. Today there are 73 federal, 209 state and 135 municipal parks, according to MMA-Cnuc, (2018).

Table 2 presents the distribution of parks by biome. Note that the Atlantic Forest has the largest number of parks in Brazil with $23,469 \mathrm{~km}^{2}$, followed by the Cerrado with $51,005 \mathrm{~km}^{2}$ and the Amazon biome with $268,707 \mathrm{~km}^{2}$. It is interesting to note that in total area the most preserved biome is the Amazon (6.4\%), followed by the Pantanal (2.8\%) and Cerrado (2.5\%) biomes. 
Table 2 | Number of parks per biome and their significance of occupation in\% - 2018.

\begin{tabular}{|c|c|c|c|}
\hline \multirow{2}{*}{ Biome } & Quantity & \% of Biome & Total Area of the Biome $\left(\mathrm{km}^{2}\right)$ \\
\hline AMAZON & 49 & 6,4 & 4.198551 \\
\hline CAATINGA & 24 & 0,9 & 827.934 \\
\hline CERRADO & 74 & 2,5 & 2.040 .167 \\
\hline ATLANTIC FOREST & 266 & 2,1 & 1.117 .571 \\
\hline PAMPA & 7 & 0,2 & 178.704 \\
\hline PANTANAL & 5 & 2,8 & 151.159 \\
\hline MARINE AREA & 41 & 0,1 & 3.555 .796 \\
\hline
\end{tabular}

In continental area there are 411 parks with a territorial extension of $355,720 \mathrm{~km}^{2}$ and representing $4.2 \%$ of the territory, which is $8,514,085 \mathrm{~km}^{2}$. In marine areas there are 41 parks with an area of 3,906 $\mathrm{km}^{2}$ and representing only $0.1 \%$ of its area, which is $3,555,796 \mathrm{~km}^{2}$ and this area corresponds to the Territorial Sea plus the Exclusive Economic Zone (MMA, 2018).

\subsection{THE CREATION OF THE PARK AND EPA OF PIRINEUS/GO}

The state of Goiás created its Forest Code in 1995 through State Law No. 12,596, regulated by Decree No. 4,593 / 95, It protects the native flora and fauna. The UCs were created in Goiás in 1959, and two National Parks were created, the Emas and the Chapada dos Veadeiros. From there, only state and municipal parks were created.

In Goiás only $4.78 \%$ of its territory is protected by UCs. Of these, $0.91 \%$ are areas of integral protection and $3.87 \%$ of sustainable use (CAMPOS; CASTRO, 2009). Furthermore, $1.72 \%$ is under the federal sphere, $3.05 \%$ state and $0.01 \%$ municipal. Untill 2017 there were 48 federal UCs (2 of these are full protection and 46 of sustainable use - Private Natural Heritage Reserve - PNHR, Environmental Protection Area - EPA and National Forest - Flona), 23 state (13 of these of full protection and 10 of Sustainable Use) - EPA, Relevant Area of Ecological Interest - Raei and State Forests) and 17 municipal ones; all full protection.

The Park of Pireneus was created by Ordinary Law 10,321 on November 20, 1987 (GOIÁS, 1987), with $2.833,26$ hectares and with the objective of preserving the natural ecosystem and all its scenic beauty. The EPA of Pirineus was created on February 17, 2000, with an area of 22,800 ha available for scientific research and cultural development to encourage preservation and education, as well as local tourism (SECIMA, 2017).

Chart 2 | Distribution of the area occupied by Pirineus Park (PEP) and EPA in the municipalities where they are covered -2018

\begin{tabular}{|c|c|c|c|c|}
\hline Municipality & $\begin{array}{c}\text { Area occupied in each } \\
\text { municipality }\left(\mathrm{Km}^{2}\right)\end{array}$ & $\begin{array}{c}\text { Percentage of Area in } \\
\text { each municipality (\%) }\end{array}$ & $\begin{array}{c}\text { Total area of the muni- } \\
\text { cipality }\left(\mathrm{Km}^{2}\right)\end{array}$ & $\begin{array}{c}\text { Percentage of occupied } \\
\text { area in each municipa- } \\
\text { lity (\%) }\end{array}$ \\
\hline PIRENÓPOLIS & 185,303008 & 65,9 & $2.235,28$ & 8,29 \\
\hline CORUMBÁ & 8,07679 & 2,9 & $1.067,18$ & 0,76 \\
\hline $\begin{array}{c}\text { COCALZINHO DE } \\
\text { GOIÁS }\end{array}$ & 87,70294 & 31,2 & $1.792,82$ & 4,89 \\
\hline
\end{tabular}

Source: Adapted and updated from Bodens (2013), Atlas Brasil (2010).

These units have their respective creation decrees, but lack the (inconclusive) management plan, infrastructure, staff and visitor control. There are expropriation problems, with 14 properties purchased, just one completed, four in court and the rest already with stipulated values deposited in court and the owners withdrew $80 \%$ of the value (SEMARH, 2018). 
Created by State Decree 5,174 / 2000 (GOIÁS, 2000), the EPA of Pireneus has the objectives of: (i) protecting the mountainous region and the surroundings of the State Park of Pireneus, in the other words, to function as a damping zone for the park; (ii) protect the remnants of Cerrado; (iii) protect water resources; (iv) improve the quality of life of resident populations by guiding and regulating local economic activities; (v) discipline ecological tourism and foster environmental education; and (vi) preserve local cultures and traditions. This way, activities that are effective or potentially causing environmental damage are prohibited or restricted (LANY; LEUZINGER; PINTO, 2006).

The EPA of Pireneus extends over 22,800 hectares around the Pireneus Park, bordering the cities of Pirenópolis, Cocalzinho de Goiás and mountainous areas of Corumbá de Goiás. The EPA has unique characteristics that make it of unique value. In this area is located the second highest massif of the state of Goiás, the Pireneus Peak with 1,380 meters altitude. The place is one of the dividers of the Tocantins and Paraná Basins. Several streams are born high in the Serra dos Pireneus, forming the Rio das Almas and the Corumbá River, which, besides their ecological importance, supply several communities in the region. It contains endemic species of amphibians and vegetables (SALMONA; RIBEIRO; MATRICARDI, 2014).

The climate in the region is tropical semi-humid characterized by two main seasons: a dry, from mid-April to mid-September, and a wet, from October to March. However, due to terrain oscillation, different microclimates may occur in higher altitude parts and in valleys or depressions. According to data from Embrapa (2010), the average temperature in the region is 22.6 o $\mathrm{C}$.

In Figure 1 can be seen the average temperature for the last 17 years for the Pirenópolis region. The temperature is held at the Meteorological Station located in Pirenópolis of number 83376. It is noticed that, on mean, this temperature has risen. Data are the responsibility of the National Institute of Meteorology (INMET, 2018).

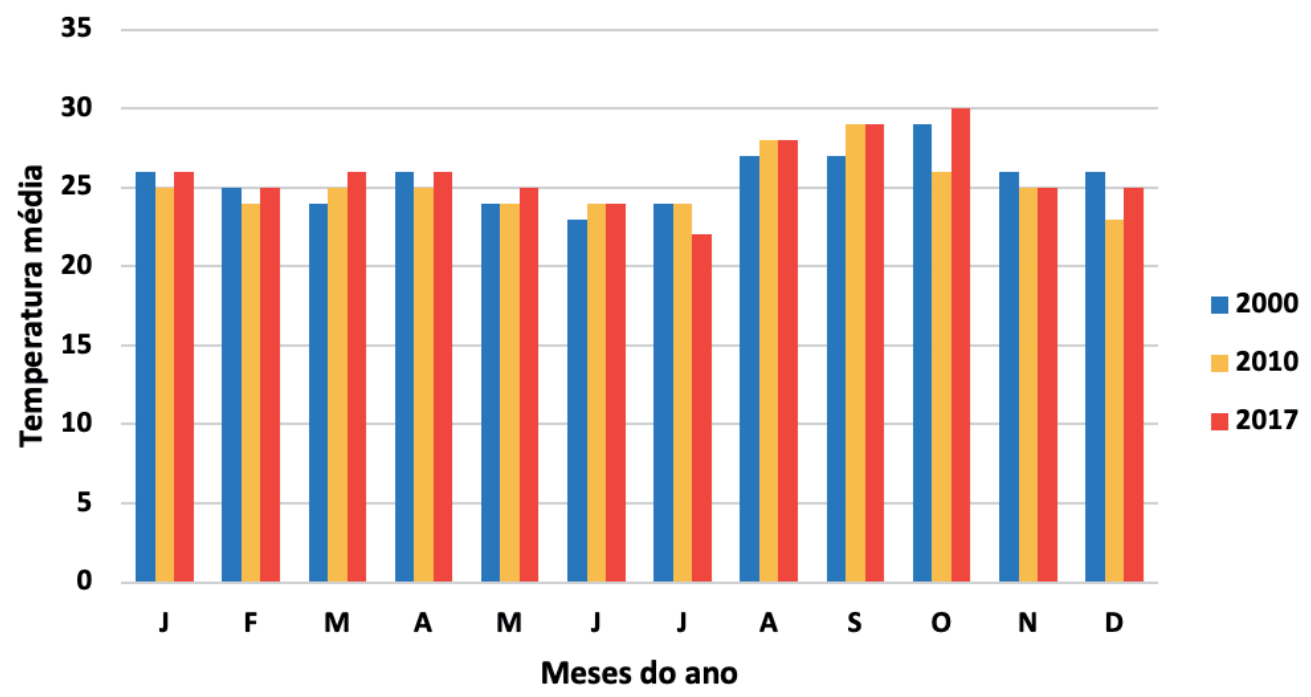

Figure 1 | Average Temperature Pirenópolis Station - 2000-2010-2017 Source: Inmet, 2018.

Park and EPA terrain are characterized by a set of saws aligned approximately in the $\mathrm{W}$ direction, with deep embedded valleys and concave slopes, with a high gradient of $20 \%$ to $45 \%$ or more, and may have vertical scarpment and amplitudes greater than $80 \mathrm{~m}$.

The whole region is part of the Cerrado biome, where 11 main types of vegetation are described for the Cerrado biome, framed in forest formations (Riparian Forest, Gallery Forest, Dry Forest and Cerradão), of savannas (Restricted Cerrado, Cerrado Park, Palm grove and Vereda) and countryside (Campo Sujo, Campo Limpo and Campo Rupestre). Considering also the subtypes in this system, 25 vegetation types are recognized (RIBEIRO; WALTER, 2001). 
The EPA area is a continental water divisor between the Paraná / Prata and Tocantins river basins, with the highest point being the Pireneus Peak. The Corumbá River, from the Prata basin, rises on the northern slope of the Pireneus Peak, bypasses the peak from the east and inflicts to the south. The Rio das Almas rises in the southwestern slope and goes around the west to Pirenópolis, when it inflicts to the north. The main watercourses in the area are the Castelhano, Araras, Dois Irmãos, São João and Inferno streams, affluent of the Rio das Almas; and Ribeirão Rasgão, an affluent of the Corumbá River.

Although the region is subjected to a prolonged annual drought period of 4 to 5 months, most watercourses are perennial. This is due to the hydrogeological characteristics of quartzites that recharge in the rainy season, slowly discharging in the dry season. The numerous waterfalls of EPA exist due to the differences in terrain and water, both having their origin in quartzites (THOMÉ FILHO; MORAES; PAULA, s.d.).

The activities present in the Pireneus EPA are mining, agriculture and tourism. It can be seen in Table 3 that agriculture occupies the largest area, followed by forest and savannah, and mining is inexpressive.

Table 3 | Different uses and soil cover of the Pireneus State Park and Pireneus EPA. Absolute area (ha) - 2016

\begin{tabular}{|c|c|c|c|c|c|c|}
\hline Cobertura & APA & $\%$ & Parque & $\%$ & TOTAL & $\%$ \\
\hline BODIES OF WATER & 5,94 & 0,03 & 0 & 0,00 & 5,94 & 0,03 \\
\hline MINING & 156,08 & 0,81 & 0 & 0,00 & 156,08 & 0,70 \\
\hline URBAN & 272,51 & 1,42 & 0 & 0,00 & 272,51 & 1,22 \\
\hline RURAL & $2.636,06$ & 13,70 & $1.342,00$ & 44,57 & $3.978,06$ & 17,88 \\
\hline SAVANNAS & $4.651,11$ & 24,17 & 618,86 & 20,55 & $5.269,97$ & 23,68 \\
\hline FORESTRY & $4.785,51$ & 24,87 & 895,39 & 29,74 & $5.680,90$ & 25,53 \\
\hline FARMING & $6.733,41$ & 35,00 & 154,79 & 5,14 & $6.888,20$ & 30,96 \\
\hline TOTAL & $19.240,62$ & 100 & $3.011,04$ & 100 & $22.251,66$ & 100 \\
\hline
\end{tabular}

Source: Adapted from Ribeiro, 2016.

\section{RESEARCH METHOD}

This is a bibliographical search. The selection of articles for research was made through electronic media, in the portal Capes, SciELO and Google Scholar. The search words were conservation units, Pirineus State Park and Pirineus EPA.

Secondary data were surveyed at the Institute of Geography and Statistics - IBGE and the Atlas of Human Development in Brazil. Socioeconomic data of the municipalities were searched: Cocalzinho de Goiás, Corumbá de Goiás and Pirenópolis. Results are presented descriptively and analytically.

In the chart 3 are the ideal characteristics, according to the method used by Oldekop et al. (2015). The method will be applied to characterize the impact on the Preservation area of the Pireneus State Park. 
Chart 3 | Characterization of the Indicators to be used for impact assessment on PAs and surrounding communities.

\begin{tabular}{|c|c|c|}
\hline & Protected Area Indicators & Characterization of the Indicators \\
\hline \multirow{4}{*}{ 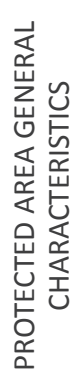 } & Protection Arrangement & Park and EPA \\
\hline & Governance & Responsible State \\
\hline & Size & Area extension \\
\hline & Phytophysiognomy & Biome \\
\hline \multirow{8}{*}{ 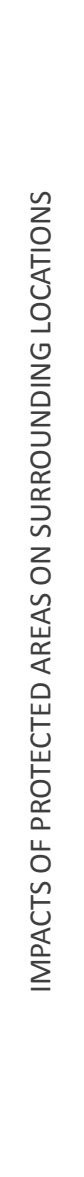 } & Displacement & $\begin{array}{l}\text { Voluntary or involuntary displacement, including movements in response } \\
\text { to changes in livelihoods }\end{array}$ \\
\hline & Monetary & $\begin{array}{l}\text { Increase or decrease in monetary wealth of any section of local } \\
\text { communities resulting from the existence of a Protected Area }\end{array}$ \\
\hline & Means of livelihoods & $\begin{array}{l}\text { Positive or negative impacts on non-monetary livelihoods (for example } \\
\text { subsistence farming, hunting and gathering of natural resources) }\end{array}$ \\
\hline & Cultural & $\begin{array}{c}\text { Impacts on cultural identity and community cohesion, access to culturally } \\
\text { important sites and resources, and aesthetic appreciation of the } \\
\text { environment }\end{array}$ \\
\hline & Compensation & $\begin{array}{l}\text { Actions by authorities responsible for Protected Areas to compensate for } \\
\text { possible negative impacts of their implementation, increase or decrease }\end{array}$ \\
\hline & Conflicts & $\begin{array}{l}\text { Protected Area staff conflicts, corruption or extortion of local people and } \\
\qquad \text { local resistance to such impacts }\end{array}$ \\
\hline & Empowerment & $\begin{array}{l}\text { Greater control over lives and livelihoods, including control over natural } \\
\text { resource management, or increased land security by local residents }\end{array}$ \\
\hline & $\begin{array}{l}\text { Uneven distribution of } \\
\text { impacts }\end{array}$ & $\begin{array}{l}\text { Impacts of Protected Areas differ between sections of neighboring } \\
\text { communities }\end{array}$ \\
\hline
\end{tabular}

Source: Adapted from Oldekop et al., 2015.

\section{RESULTS AND DISCUSSIONS}

\subsection{SOCIAL, ECONOMIC AND POPULATION OF THE BORDER MUNICIPALS TO THE PIRENEUS}

The region that makes up the boundaries of the Pirineus EPA is made up of the municipalities of Pirenópolis, Corumbá de Goiás and Cocalzinho de Goiás. It comprises an area of 5,078.24 km² and an estimated population for 2018 of 54,268 inhabitants with an average demographic density of 10.69 $\mathrm{hab} / \mathrm{km}^{2}$ (IBGE, 2016). About $41.19 \%$ of this population lives in rural areas, see Table 4.

The municipality that most increased its population was Cocalzinho de Goiás (19.01\%) and was also the one that most populated the rural area (27.09\%). This settlement is due to the displacement of cement 
industry workers from the Votorantim de Cocalzinho group that closed in 2000. The population turned to the opportunity for economic gains through rural tourism and visits to the Pireneus UC.

Table 4 | Population dynamics of municipalities bordering Pireneus EPA and Pireneus State Park / GO - 2000-2010

\begin{tabular}{|c|c|c|c|}
\hline \multirow{2}{*}{ Population Data } & \multicolumn{3}{|c|}{ Municipality } \\
\cline { 2 - 4 } & Pirenópolis & $\begin{array}{c}\text { Corumbá de } \\
\text { Goiás }\end{array}$ & Cocalzinho de Goiás \\
\hline TOTAL POPULATION 2000 & 21.245 & 9.679 & 14.626 \\
\hline TOTAL POPULATION 2010 & 23.006 & 10.361 & 17.407 \\
\hline PERCENTAGE CHANGE & 8,29 & 7,08 & 19,01 \\
\hline RURAL POPULATION 2000 & 8.770 & 4.082 & 8.626 \\
\hline RURAL POPULATION 2010 & 7.443 & 3.945 & 10.963 \\
\hline PERCENTAGE CHANGE & $-91,16$ & $-3,36$ & 27,09 \\
\hline URBAN POPULATION 2000 & 12.475 & 5.597 & 6.000 \\
\hline URBAN POPULATION 2010 & 15.563 & 6.416 & 6.444 \\
\hline PERCENTAGE CHANGE & 24,75 & 14,63 & 7,4 \\
\hline
\end{tabular}

Source: Ipea, 2010.

Of the municipalities bordering the Pireneus Park and EPA, the one that most improved its income distribution and human development indicators in the last ten years was Corumbá de Goiás, with Gini index $(-15 \%)$ with the HDI of the most significant municipality with an increase of $36 \%$. Regarding the population classified among the extremely poor, it was found that Pirenópolis reduced it by $84 \%$, Corumbá de Goiás by $72 \%$ and Cocalzinho de Goiás by $62 \%$. The number of people vulnerable to poverty had a smaller reduction in municipalities, with $57 \%, 55 \%$ and $56 \%$ respectively (see Table 5 ). These results are due to public policies implemented in the state of Goiás for development, which in the case of these municipalities, are linked to tourism in the region called Ouro e Cristais in Goiás.

Table 5 | Social dynamics bordering the Pyrenees APA and Pireneus State Park / GO - 2000-2010

\begin{tabular}{|c|c|c|c|}
\hline \multirow{2}{*}{ Social Data } & \multicolumn{3}{|c|}{ Municipality } \\
\cline { 2 - 4 } & Pirenópolis & $\begin{array}{c}\text { Corumbá de } \\
\text { Goiás }\end{array}$ & Cocalzinho de Goiás \\
\hline GINI INDEX 2000 & 0,55 & 0,60 & 0,51 \\
\hline GINI INDEX 2010 & 0,49 & 0,51 & 0,47 \\
\hline PERCENTAGE CHANGE & $-10,91$ & $-15,00$ & $-7,84$ \\
\hline HDI 2000 & 0,565 & 0,50 & 0,506 \\
\hline HDI 2010 & 0,693 & 0,68 & 0,657 \\
\hline PERCENTAGE CHANGE & 22,65 & 36,00 & 29,84 \\
\hline EXTREMELY POOR PEOPLE (\%) 2000 & 11,58 & 14,26 & 15,42 \\
\hline EXTREMELY POOR PEOPLE (\%) 2010 & 1,88 & 4,04 & 5,91 \\
\hline PERCENTAGE CHANGE & $-83,77$ & $-71,67$ & $-61,67$ \\
\hline VULNERABLE TO POVERTY (\%) 2000 & 31,34 & 36,64 & 38,14 \\
\hline VULNERABLE TO POVERTY (\%) 2010 & 13,35 & 16,64 & 16,83 \\
\hline
\end{tabular}

Source: Pnud, Ipea, 2010. 
The information shown in Table 6 shows that the municipality that had a significant growth was Pirenópolis, with a 137\% increase in Gross Domestic Product (GDP), boosted by the mineral industry and tourism in various ways, followed by Corumbá de Goiás also having Ecotourism as a growth lever. (See Table 6). The tourism sector has been boosted through federal government incentive policies, such as the Midwest Constitutional Fund MCF-tourism, and the state through the Tourism Development in Historic Cities program.

Table 6 | Economical dynamics bordering the Pyrenees APA and Pireneus State Park / GO - 2000-2010

\begin{tabular}{|c|c|c|c|}
\hline \multirow{2}{*}{ Economic Indicators } & \multicolumn{2}{|c|}{ Municipality } \\
\cline { 2 - 4 } & Pirenópolis & $\begin{array}{c}\text { Corumbá de } \\
\text { Goiás }\end{array}$ & Cocalzinho de Goiás \\
\hline PER CAPITA INCOME 2000 & 356,28 & 370,44 & 272,38 \\
\hline PER CAPITA INCOME 2010 & 544,78 & 503,01 & 450,47 \\
\hline PERCENTAGE CHANGE & 52,90 & 35,79 & 65,38 \\
\hline MUNICIPAL GDP (R\$) 2005 & $103.362,00$ & $68.041,00$ & $243.854,00$ \\
\hline MUNICIPAL GDP (R\$) 2010 & $244.745,00$ & $116.957,00$ & $285.878,00$ \\
\hline PERCENTAGE CHANGE & 137 & 72 & 17 \\
\hline DEGREE OF URBANIZATION 2000 & 58,72 & 57,82 & 41,03 \\
\hline DEGREE OF URBANIZATION 2010 & 67,65 & 61,95 & 37,02 \\
\hline PERCENTAGE CHANGE & 15,21 & 7,14 & $-9,77$ \\
\hline
\end{tabular}

Source: Ipea, 2010.

With a different vision at Table 7, we realize that the municipality of Corumbá de Goiás was able to match the other two municipalities in terms of supply and access to drinking water, solid waste collection and electricity supply to its residents. Between 2000 and 2010, the number of households with piped water increased by $15.88 \%$, electricity by $12.64 \%$ and garbage collection by $32.63 \%$, much higher than the state average of $10.95 \%$ for $2.33 \%$ for electricity and $0.69 \%$ for garbage collection (IPEA, 2010).

Table 7 | Housing indicators of municipalities bordering the Pireneus EPA and Pireneus State Park / GO - 2000-2010

\begin{tabular}{|c|c|c|c|}
\hline \multirow{2}{*}{ Housing Indicators } & \multicolumn{3}{|c|}{ Municipality } \\
\cline { 2 - 4 } & Pirenópolis & $\begin{array}{c}\text { Corumbá de } \\
\text { Goiás }\end{array}$ & $\begin{array}{c}\text { Cocalzinho de } \\
\text { Goiás }\end{array}$ \\
\hline HOUSEHOLDS WITH PIPED WATER (\%) 2000 & 79,55 & 77,50 & 82,12 \\
\hline HOUSEHOLDS WITH PIPED WATER (\%) 2010 & 91,12 & 89,81 & 94,39 \\
\hline PERCENTAGE CHANGE & 14,54 & 15,88 & 14,94 \\
\hline HOUSEHOLDS WITH ELECTRICITY (\%) 2000 & 92,35 & 87,57 & 90,85 \\
\hline HOUSEHOLDS WITH ELECTRICITY (\%) 2010 & 99,85 & 98,64 & 99,31 \\
\hline PERCENTAGE CHANGE & 8,12 & 12,64 & 9,31 \\
\hline HOUSEHOLDS WITH GARBAGE COLLECTION (\%) 2000 & 97,72 & 73,88 & 77,93 \\
\hline HOUSEHOLDS WITH GARBAGE COLLECTION (\%) 2010 & 99,43 & 97,99 & 97,20 \\
\hline PERCENTAGE CHANGE & 1,75 & 32,63 & 24,73 \\
\hline
\end{tabular}

Source: Ipea, 2010.

Regarding the indicators of sanitary sewage and care with public roads, the best results were verified in the municipality of Pirenópolis, for afforestation (83.60\%) and sanitary sewage (33.90\%), and in Corumbá de Goiás, with urbanization. (19.90\%). The importance given to urban afforestation can be expected to be closely related to tourism, while urbanization and sewage collection services are more closely related to economic growth. (See Table 8). 
Table 8 | Sanitation and environment indicators of municipalities bordering the Pirineus EPA and Pireneus State Park / GO - 2016.

\begin{tabular}{|c|c|c|c|}
\hline \multirow{2}{*}{ Indicators } & \multicolumn{3}{|c|}{ Municipality } \\
\cline { 2 - 4 } & Pirenópolis & Corumbá de Goiás & \multirow{2}{*}{ Cocalzinho de Goiás } \\
\hline AFFORESTATION OF PUBLIC ROADS & 83,60 & 76,70 & 60,90 \\
\hline URBANIZATION OF PUBLIC ROADS & 9,00 & 19,90 & 0,00 \\
\hline SANITARY SEWAGE & 33,90 & 26,70 & 18,40 \\
\hline
\end{tabular}

\subsection{CHARACTERIZATION OF THE CONSERVATION UNIT'S IMPACT ON MUNICIPALITIES}

Figure 2 shows a chronological analysis of land use in the Pireneus EPA. Map A refers to 1988, B 1998, C 2008 and D 2018. The temporal analysis of the use and occupation of the Serra dos Pireneus Environmental Protection Area was performed using Landsat- 5 satellite images and Landsat- 8 taken from the catalog at Inpe's General Imaging Division. Land use and occupation classification in the Serra dos Pireneus EPA was carried using ArcGis 10.1 software using the Maximum Likelihook Classification method. This method consists of obtaining samples of different classes found in the satellite image.

It is noted that there is a large exposure of soils in the analyzed years (increase in the last 30 years of $1,789.21 \%$ ) that can characterize both population increase and mining activity. Remembering that the region has large production of quartzite, also known as Pedra de Pirenópolis, which is widely used in civil construction for ornamentation of houses, floors and streets, among others.

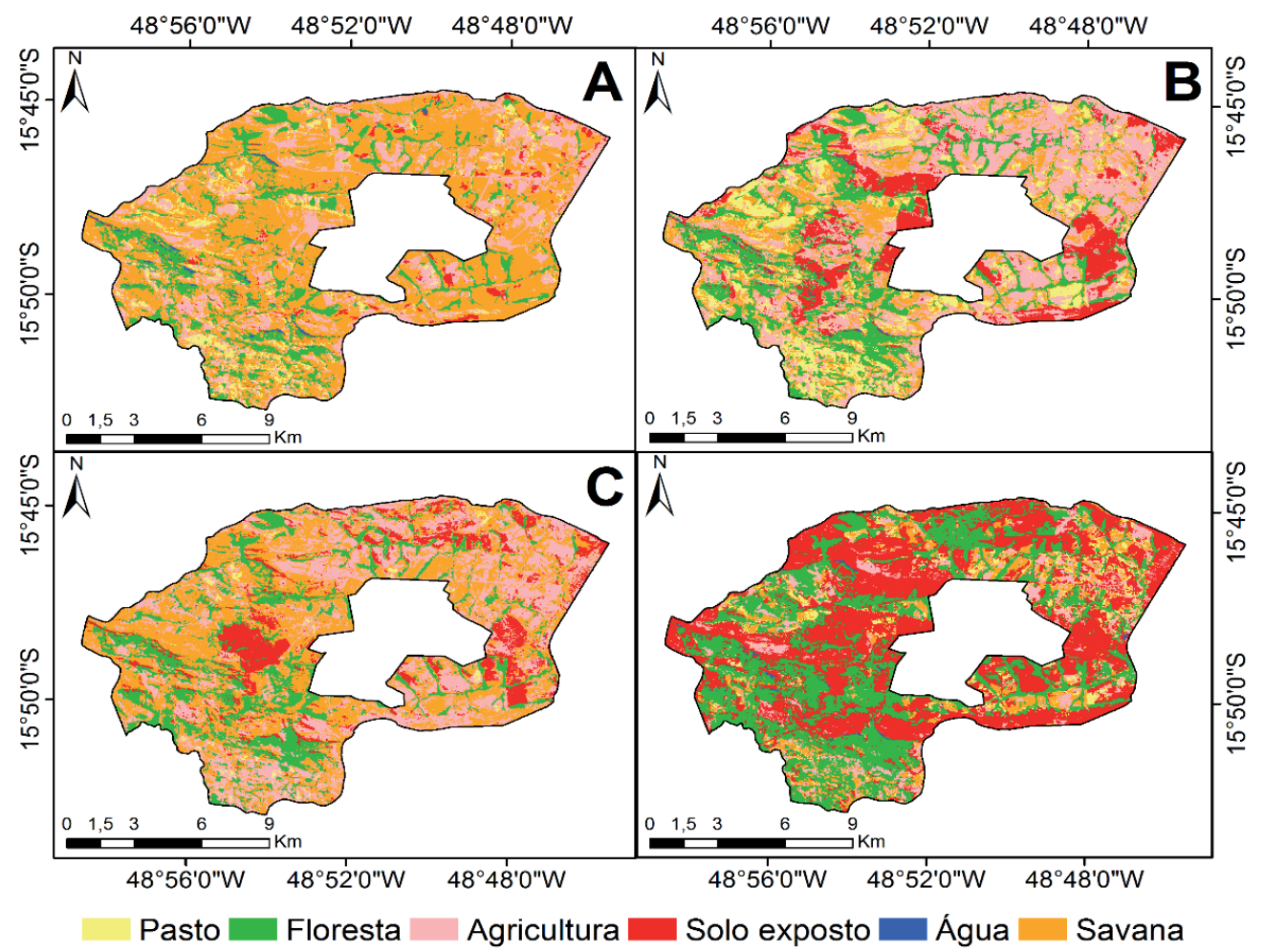

Figure 2 | Land use on Pireneus EPA /GO - 1988, 1998, 2008 e 2018. Source: own elaboration.

Table 9 shows that pasture area decreased by $17.29 \%$, agriculture area by $60.64 \%$ and savanna (cerrado) by $82.62 \%$. Also of concern is the decrease in the water portion which was $19.56 \%$. In the last 30 years, the area has had a forest growth of about $141.43 \%$. Decline in the proportion of land use for agriculture and livestock is mainly supported by the eviction of properties in the park area and, 
secondly, by the increase in ecotourism and adventure tourism in the Pireneus UC. This increase in forest area occurred because there are more than 70 hectares of protected areas in the region, these are Private Natural Heritage Reserves (PNHRs) that are being implemented. It is the densest mosaic in the country (RPPN / ha) (RESENDE, 2019). This drastic reduction in savannah (cerrado stricto sensu) areas is extremely worrying in terms of biodiversity loss belonging exclusively to this phytophysiognomy, and can be considered as another indication that there is a differentiation of concern between the phytophysiognomies present in the Cerrado, a result of less scenic beauty of this landscape, given the forest formations.

Tabela 9 | Land use on Pireneus EPA/GO - 1988-2018

\begin{tabular}{|c|c|c|c|c|c|}
\hline Class & 1988 & 1998 & 2008 & 2018 & Variation \\
\hline PASTURE & 11.368 & 26.285 & 2.004 & 9.402 & $-17,29$ \\
\hline FOREST & 30.637 & 43.482 & 37.116 & 73.966 & 141,43 \\
\hline AGRICULTURE & 47.668 & 71.154 & 65.404 & 18.763 & $-60,64$ \\
\hline EXPOSED SOIL & 4.756 & 27.526 & 24.314 & 89.851 & $1.789,21$ \\
\hline WATER & 956 & 360 & $27\left(^{1}\right)$ & 769 & $-19,56$ \\
\hline SAVANNA & 117.853 & 44.442 & 85.157 & 20.495 & $-82,61$ \\
\hline TOTAL & 213.238 & 213.249 & 214.022 & 213.246 & 0,000038 \\
\hline
\end{tabular}

Source: own elaboration.

Note (1) I Some satellite images do not very clearly display pixels with water information. This can be due to the time of year the image was taken by the satellite, as it is very closely related to the reflectance level of the targets.

Chart 4 presents the main indicators. According Oldekop et al. (2015) about the characteristics and impacts of UCs. Those indicators show the interrelations between protected areas and their neighboring municipalities.

Chart 4 | Indicators of Pireneus EPA areas and Pireneus State Park/GO - 2019

\begin{tabular}{|c|c|c|}
\hline & Protected Area Indicators & Characterization of the Indicators \\
\hline \multirow{4}{*}{ 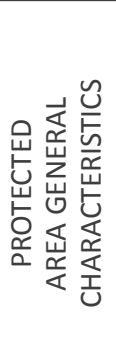 } & $\begin{array}{l}\text { PROTECTION } \\
\text { ARRANGEMENT }\end{array}$ & $\begin{array}{l}\text { Pireneus EPA } \\
\text { Pireneus Park }\end{array}$ \\
\hline & GOVERNANCE & State of Goiás \\
\hline & SIZE & $\begin{array}{l}\text { Park: } 2.833,26 \text { hectares } \\
\text { EPA: } 22.800 \text { ha }\end{array}$ \\
\hline & PHYTOPHYSIOGNOMY & Biome: Cerrado \\
\hline \multirow{3}{*}{ 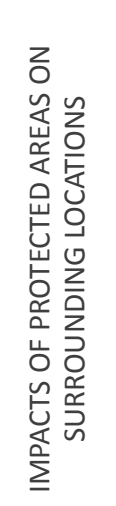 } & DESPLACEMENTS & $\begin{array}{c}\text { The largest displacement in the rural area was from Pirenópolis with a } \\
\text { displacement of } 91.16 \% \text { of the rural population to the urban area. And in } \\
\text { Cocalzinho de Goiás the moving was in the opposite direction, there was an } \\
\text { increase of rural population of } 27.09 \%\end{array}$ \\
\hline & MONETARY & $\begin{array}{c}\text { Appropriation of natural heritage by the tourism sector. } \\
\text { Real estate speculation }\end{array}$ \\
\hline & MEANS OF LIVELIHOODS & $\begin{array}{l}\text { Agroecological production by resident communities. } \\
\text { Organic production. } \\
\text { Subsistence farming. } \\
\text { Homemade production of food with fruits of the Cerrado. } \\
\text { Household planting of medicinal plants }\end{array}$ \\
\hline
\end{tabular}




\begin{tabular}{|c|c|c|}
\hline \multirow{5}{*}{ 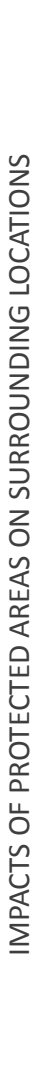 } & CULTURAL & $\begin{array}{c}\text { Cerrado Gastronomy - Knowledge and flavors. } \\
\text { Courses on fruits of the Cerrado. } \\
\text { Pirenópolis photographic marathon. } \\
\text { Bio Floresta - permaculture courses. } \\
\text { Pirenópolis Literary Fair } \\
\text { Festival of the Divine Holy Spirit - Cavalhadas. } \\
\text { Sports Scale - Bouder } \\
\text { Sites that promote the sights of cities and parties. }\end{array}$ \\
\hline & COMPENSATION & $\begin{array}{l}\text { NGO work influencing the incorporation or maintenance of proactive } \\
\text { conservation attitudes. } \\
\text { Tourism is the 3rd source of revenue from the municipalities. }\end{array}$ \\
\hline & CONFLICTS & $\begin{array}{c}\text { Expropriation of } 14 \text { rural properties to compose the EPA space and park. } \\
\text { Handling of } 4 \text { expropriation lawsuits. } \\
\text { Partial payments of } 10 \text { landowners - deposits in court for payment of } \\
\text { territorial space. } \\
\text { Breach of Law } 9.985 \text { / } 00 \text { art. } 11 \text { There are no environmental education } \\
\text { projects for the conservation unit. }\end{array}$ \\
\hline & EMPOWERMENT & $\begin{array}{l}\text { Stone and plant crafts by women. } \\
\text { Popular medicine - Cerrado roots. } \\
\text { Smallholder agribusiness - baru, pequi, jatobá, cagaita, Cerrado vanilla and } \\
\text { cashew made by communities such as Caxambu and } 22 \text { others in Pirenópolis. }\end{array}$ \\
\hline & $\begin{array}{l}\text { UNEVEN DISTRIBUTION OF } \\
\text { IMPACTS }\end{array}$ & $\begin{array}{c}\text { Unsupervised protected areas generating depredation of the natural heritage } \\
\text { by removing orchids, bromeliads and other plants from the site. } \\
\text { Depredation of public patrimony with graffiti and vandalism, presence of } \\
\text { erosion in the visitation trails. } \\
\text { Fires in the UC. Trash scattered throughout the park. }\end{array}$ \\
\hline
\end{tabular}

Source: Data extracted from the texts of Garcia, Koop and Godoi (2015); Godinho and Oliveira (2010); Souza, Nunes and Santos (2015); Zaneti and Balestro (2015)

Indicators of the Pireneus Park and EPA areas show a radiograph of the current symbiotic relationship between bordering municipalities and the active participation of the Pirineus UC. The population displacement from Pirenópolis to the urban area is due to the incentive of commerce related to tourism in the municipality, both gastronomic (Cerrado Goian cuisine), ecotourism and adventure tourism. And the displacement of the population from Cocalzinho to the rural area was due to the dynamism of ecotourism in several properties, as the cement industry that generates jobs and income closed in 2010.

There is also a growing involvement of the population in agroecological exploration in the place with improvement of typical foods and sweets with fruits of the Cerrado, handicrafts with stones, seeds and flowers acquired at Pirineus UCS.

\section{FINAL CONSIDERATIONS}

Neighboring municipalities had an average HDI development in the years surveyed by $30 \%$, and a decrease in the Gini Index of $11.25 \%$ resulting in a decrease in income inequality. As for growth data and indicators, neighboring municipalities had a 51\% increase in GDP and per capita income closely linked to UC, such as tourism and commerce.

There is much speculation that the creation of a PA will hinder the growth or development of the region, since its creation may impede the installation of industries and the dynamization of agriculture. In the case of neighboring municipalities, this fact did not occur, the creation of the UC allowed the promotion of tourism through new companies in the field related to hotels and regional trade of land products that generate employment and local income. The creation of the Pireneus UCs changed the socio-cultural context of the region provided by the flow of tourists. 
It would be fair to conclude that the economic impact of setting up conservation units for neighboring municipalities will depend on public policies and changing paradigms in the private sector. Both should seek to identify the opportunities created for the increase of tourism and commercialization of specialized products, which arrive with great added value due to the exclusivity and sustainability character attributed to them.

\section{ACKNOWLEDGEMENTS}

To the Conselho Nacional de Desenvolvimento Cientifico e Tecnológico - CNPq for funding the research and scientific initiation scholarships. Financial support from the Fundação de Amparo à Pesquisa do Estado de Goiás (Fapeg) in agreement with th Coordenação de Aperfeiçoamento de Pessoal de Nível Superior (Capes). To the Universidade Estadual de Goiás and the Núcleo de Estudos e Pesquisas em Economia Nepe/UEG.

\section{REFERENCES}

BODENS, J. Diretrizes para avaliação do impacto ambiental da prática de boulder em Parques Nacionais e Estaduais: o caso do Parque Estadual dos Pireneus (GFO). Universidade de Brasília - Departamento de Geografia, 2013.

BRASIL. Lei 9.985. Regulamenta o art. 225, § 10, incisos I, II, III e VII da Constituição Federal, institui o Sistema Nacional de Unidades de Conservação da Natureza e dá outras providências. 2000.

BRASIL. Ministério do Meio Ambiente - MMA-Cnuc. Tipos de Unidades de Conservação. Disponível em: <http:// www.mma .gov. br/>. Acesso em: 09 jun. 2018.

CAMPOS, A. C.; CASTRO, S. S. Aspectos da legislação ambiental no estado de Goiás e a distribuição espacial das unidades de conservação no Cerrado goiano. I SIMPÓSIO AMBIENTALISTA DA UNIVERSIDADE ESTADUAL DE GOIÁS. Anais... Anápolis, 2009.

GARCIA, D. DE L. R.; KOOP, K.; GODOI, E. L. Percepção ambiental como avaliação da efetividade da APA dos Pireneus - Goiás. Revista Eletrônica de Engenharia Civil. Goiânia, v. 10, n. 1, 2015.

GODINHO, R. G.; OLIVEIRA, I. J. Análise e avaliação da distribuição geográfica da infraestrutura turística no sítio histórico de Pirenópolis/GO: subsídios ao planejamento turístico. Boletim Goiano de Geografia. Goiânia, v. 30, n. 1, jan./jun., 2010.

GOIÁS. DECRETO № 5.174, DE 17 DE FEVEREIRO DE 2000. Dispõe sobre a criação da Área de Proteção Ambiental dos Pireneus e dá outras providências. Disponível em:<http://www. gabinetecivil.goias. gov.br/decretos/ numerados/2000/decreto_5174. htm>. Acesso em: set. 2017.

GOIÁS. LEI № 10.321, DE 20 DE NOVEMBRO DE 1987. Cria o Parque Estadual dos Pireneus e dá outras providências. Disponível em: <http://www.gabinetecivil. goias.gov.br/leis_ordinarias/1987/lei_10321.htm>. Acesso em: out. 2017.

INSTITUTO BRASILEIRO DE GEOGRAFIA E ESTATÍSTICA - IBGE. Dados geográficos 2016. Disponível em: <https:// cidades.ibge.gov.br/brasil/go/panorama>. Acesso em: 16 abr. 2018.

INSTITUTO DE PESQUISA ECONÔMICA APLICADA - IPEA. Índice de Gini - 2010. Disponível em: <http://www.ipea. gov.br/desafios/index.php? option=com_content\&id=2048:catid=28>. Acesso em: 10 jul. 2018.

INSTITUTO NACIONAL DE METEOROLOGIA - INMET. Temperatura média na Região dos Pireneus. Disponível em: <http://www.inmet.gov.br/portal/>. Acesso em: 14 fev. 2019.

LAMY, A. C. M.; LEUZINGER, M. D.; PINTO, M. O. Rodovia em Unidade de Conservação: o caso da Estrada Parque 
dos Pireneus (GO). III ENCONTRO DA ANPPAS. Anais... 23 a 26 de maio de 2006. Brasília-DF, 2007.

LEUZINGER, M. D. Uso Público em Unidades de Conservação. Congresso de Direito Ambiental da PUC-RIO, Anais... 1., 2010, Rio de Janeiro. Disponível em: <http:// www.nima.pucrio. br/aprodab/artigos/uso_publico_ em_unidades de_conservacao_marcia_leuzinger.pdf>. Acesso em: abr. 2018.

Natureza e Cultura: unidades de conservação de proteção integral e populações tradicionais residentes. Curitiba: Letras da Lei, 2009.

OLDEKOP, J. A. et al. A global assessment of the social and conservation outcomes of protected areas. Conservation Biology, v. 30, n. 1, p. 133-141, 2015.

PENA, I. A. DE B.; SANTOS, C. J. F.; SINAY, L. Estratégias para o desenvolvimento do uso público das APAs dos Morros da Babilônia e São João do Leme e Urubu e Parque Estadual da Chacrinha, RJ. CONGRESSO EM USO PÚBLICO EM UNIDADES DE CONSERVAÇÃO. Universidade Federal Fluminense, Niterói/RJ. Anais ... n. 1, v. 1, 2013. Disponível em: <http://www.uff.br/usopublico>. Acesso em: abr. 2018.

RESENDE, P. Mais uma reserva particular foi criada em Pirenópolis. G1 15/08/2019. Disponível em: <https:// g1.globo.com/go/goias/noticia/2019/08/15/ pirenopolis -ganha-mais-uma-reserva-particular-do-patrimonionatural-e-forma-mosaico-de-protecao-da-serra-dos-pireneus.ghtml>. Acesso em: out. 2019.

RIBEIRO, J. F.; WALTER, B. M. T. Tipos de vegetação do Bioma Cerrado. [s.l.]: EMBRAPA, 2001. Disponível em: <http://www.agencia.cnptia.embrapa. br/Agencia16/AG01 /arvore/AG01_23_91 1200585232.html>. Acesso em: set. 2017.

ROCHA, L. G. M.; DRUMMOND, J. A.; GANEM, R. S. Parques nacionais brasileiros: problemas fundiários e alternativas para sua resolução. Revista de Sociologia Política, Curitiba, v. 18, n. 36, 2010.

SAlgAdO, G. S. M. Economia e Gestão de Áreas Protegidas: o caso do Parque Nacional de Brasília. Brasília, 2000, 124 p. Dissertação (Mestrado em Gestão Econômica do Meio Ambiente) - Universidade de Brasília - UnB, Instituto de Ciências Humanas, Departamento de Economia.

SALMONA, Y. B.; RIBEIRO, F. F.; MATRICARDI, E. A. Parques no papel conservam? O caso do Parque dos Pireneus em Goiás. Boletim Goiano de Geografia. (On-line). Universidade Federal de Goiás. Goiânia. v. 34, n. 2, maio/ago., 2014.

SANTOS, S. A. As Unidades de Conservação no Cerrado Frente ao Processo de Conversão. Dissertação (Mestrado) - Universidade Federal de Goiás, Instituto de Estudos Socioambientais (lesa), Programa de Pós-Graduação em Geografia, Goiânia, 2018.

SECRETARIA DO MEIO AMBIENTE, RECURSOS HÍDRICOS, INFRAESTRUTURA, CIDADES E ASSUNTOS METROPOLITANOS - SECIMA. UCs Estaduais: áreas de proteção ambiental dos Pireneus. 2017. Disponível em: <http://www.secima.go.gov.br>. Acesso em: set. 2017.

SOUSA, R. G.; NUNES, V. H. A.; SANTOS, M. L. O Ecoturismo, o meio ambiente e o Parque Estadual da Serra dos Pireneus na percepção dos visitantes e moradores de Pirenópolis/GO. Revista Brasileira de Ecoturismo. São Paulo, v. 8, n. 2, mai/ago 2015.

THOMÉ FILHO, J. J.; MORAES, J. M.; PAULA, T. L. F. Geoparque Pireneus (GO). Geoparques do Brasil / Propostas, v. 1, [s.d.].

UNEP, U. N. E. P. Protected Planet Report 2016. How protected areas contribute to achieving global targets for biodiversity. [s.I: s.n.]. 2016.

ZANETI, T. B.; BALESTRO, M. V. Valoração de produtos tradicionais no circuito gastronômico: lições do Cerrado. Sustentabilidade em Debate, Brasília, v. 6, n. 1, jan/abr. 2015. 